\title{
Classification of "Chromobacterium marismortui' in a New Genus, Chromohalobacter gen. nov., as Chromohalobacter marismortui comb. nov., nom. rev.
}

\author{
A. VENTOSA, * M. C. GUTIERREZ, M. T. GARCIA, AND F. RUIZ-BERRAQUERO \\ Department of Microbiology, Faculty of Pharmacy, University of Seville, Seville, Spain
}

\begin{abstract}
Phenotypic and chemotaxonomic characteristics of seven moderately halophilic isolates from a mediterranean saltern showed that they were very closely related to "Chromobacterium marismortui." This species, which was originally described on the basis of strains isolated from the Dead Sea, was not included on the Approved Lists of Bacterial Names and is not accepted as a member of the genus Chromobacterium since it produces a pigment that is not violacein, does not possess the characteristic flagellar arrangement, and is not genotypically related to this genus as determined by deoxyribonucleic acid-ribosomal ribonucleic acid hybridization experiments. On the basis of the special features of these strains, we propose that they should be placed in a new genus, Chromohalobacter, which includes a single species, Chromohalobacter marismortui comb. nov., nom. rev. The deoxyribonucleic acid base composition is 62.1 to $64.9 \mathrm{~mol} \%$ guanine plus cytosine. The type strain is strain ATCC 17056 (= CCM 3518).
\end{abstract}

Moderately halophilic bacteria are organisms that are able to grow optimally in media containing between 3 and $15 \%$ (wt/vol) $\mathrm{NaCl}(22)$. This physiological group of microorganisms includes several gram-negative eubacteria $(10,12,14$, $16,20,28,29,34,41,43$; B. Elazari-Volcani, Ph.D. thesis, Hebrew University, Jerusalem, Israel, 1940) and grampositive eubacteria $(5,15,27)$, as well as some archaebacteria $(26,33,42)$.

In 1940, Elazari-Volcani (Ph.D. thesis) described a moderately halophilic bacterium, "Chromobacterium marismortui," that was isolated from the Dead Sea. This species was described in Bergey's Manual of Determinative Bacteriology, 7th ed. (2), and in Bergey's Manual, 8th ed. (3). It was included in the genus Chromobacterium as a species incertae sedis since it did not produce violacein and lacked the typical flagellar arrangement of the genus Chromobacterium. It was not included on the Approved Lists of Bacterial Names (36).

In a previous study we isolated from a saltern seven strains with some morphophysiological and biochemical characteristics similar to those of this species (40). The purpose of this study was to compare our isolates with the original species "Chromobacterium marismortui" and to determine their taxonomic position.

\section{MATERIALS AND METHODS}

Bacterial strains. We studied seven strains (strains A-56, A-65, A-100, A-102, A-429, A-431, and A-492) which were isolated from water samples collected from ponds with salinities between 22.2 and $29.0 \%$ (wt/vol) total salts of a commercial solar saltern located near Alicante, Spain, between February 1979 and January 1980 (40). We also studied "Chromobacterium marismortui" ATCC $17056^{\mathrm{T}}$ ( $\mathrm{T}=$ type strain) and one subculture of the original strain, which was kindly provided by B. Elazari-Volcani, Scripps Institution of Oceanography, La Jolla, Calif. For comparative purposes the following strains were also used: Chromobacterium violaceum ATCC $12472^{\mathrm{T}}$, Janthinobacterium lividum ATCC $12473^{\mathrm{T}}$, Alteromonas luteoviolacea ATCC $33492^{\mathrm{T}}$, Vibrio costicola NCMB $701^{\mathrm{T}}$, Deleya halophila CCM $3662^{\mathrm{T}}$, Flavobacterium halmephilum $\mathrm{CCM} 2833^{\mathrm{T}}$, Halomonas elon-

\footnotetext{
* Corresponding author.
}

gata ATCC 33173 T, and "Pseudomonas halosaccharolytica' CCM 2851.

Strains were maintained on agar slants containing $10 \%$ (wt/vol) salts with the following composition: $8.1 \%$ (wt/vol) $\mathrm{NaCl}, 0.7 \%$ (wt/vol) $\mathrm{MgCl}_{2}, 0.96 \%$ (wt/vol) $\mathrm{MgSO}_{4}, 0.036 \%$ (wt/vol) $\quad \mathrm{CaCl}_{2}, 0.2 \%$ (wt/vol) $\mathrm{KCl}, 0.006 \%$ (wt/vol) $\mathrm{NaHCO}_{3}$, and $0.0026 \%$ (wt/vol) $\mathrm{NaBr}$. This preparation was supplemented with $0.5 \%$ (wt/vol) Proteose Peptone no. 3 (Difco Laboratories, Detroit, Mich.), 1\% (wt/vol) yeast extract (Difco), and $0.1 \%$ (wt/vol) glucose (12). The $\mathrm{pH}$ was adjusted to 7.5 with $1 \mathrm{M} \mathrm{KOH}$. When required, agar (Difco) was added to a concentration of $2 \%$ (wt/vol).

Phenotypic characterization. Tests for 107 characteristics, including morphological, physiological, biochemical, and nutritional features, were carried out. The methodology used has been described previously $(12,34,40)$. Unless otherwise indicated, all tests were performed in media containing $10 \%$ (wt/vol) salts and with a $\mathrm{pH}$ of 7.5 , and incubation was at $37^{\circ} \mathrm{C}$ in sealed containers.

Oxidase was determined by the Kovacs (21) and GabyHadley methods (11). The benzidine test (6) was used to detect porphyrin-containing enzyme systems. Utilization of carbohydrates was determined by using modified marine oxidation-fermentation medium (23) supplemented with $10 \%$ (wt/vol) total salts and the following sugars: D-glucose, $\mathrm{D}$-galactose, glycerol, D-arabinose, trehalose, maltose, Dmannitol, lactose, sucrose, and D-xylose. We also used the conventional oxidation-fermentation medium of Hugh and Leifson (17) supplemented with $8 \%$ (wt/vol) $\mathrm{NaCl}$ and glucose, as well as standard medium (18) supplemented with $10 \%$ (wt/vol) salts and different sugars.

DNA base composition. Exponential-phase cells of strains were ruptured, and the deoxyribonucleic acid (DNA) was purified by using the method of Marmur (24). The guanineplus-cytosine $(\mathrm{G}+\mathrm{C})$ content of the DNA was determined from the midpoint value of the thermal denaturation profile (25), which was obtained with a model UV-Vis 551S spectrophotometer (The Perkin-Elmer Corp., Norwalk, Conn.) at $260 \mathrm{~nm}$; this instrument was programmed for temperature increases of $1.0^{\circ} \mathrm{C} / \mathrm{min}$. The midpoint of the thermal denaturation profile was determined by a graphic method as described by Ferragut and Leclerc (9), and the $\mathrm{G}+\mathrm{C}$ content 
was calculated from this temperature by using the equation of Owen and Hill (30) in $0.1 \times \mathrm{SSC}(1 \times \mathrm{SSC}$ is $0.15 \mathrm{M} \mathrm{NaCl}$ plus $0.015 \mathrm{M}$ trisodium citrate, $\mathrm{pH} 7.0$ ). The midpoint of the thermal denaturation profile for reference DNA from $E s c h$ erichia coli NCTC 9001 was taken to be $74.6^{\circ} \mathrm{C}$ in $0.1 \times \mathrm{SSC}$ (31).

Preparation of labeled DNA. DNA was labeled by using the multiprime system, a commercial kit (kit RPN 1601Y; Amersham International, Amersham, England), and $\left[{ }^{3} \mathrm{H}\right]$ deoxy $\left(1^{\prime}, 2^{\prime}, 5\right)$ cytidine $5^{\prime}$-triphosphate (Amersham). The average specific activity obtained with this procedure was 8.4 $\times 10^{6} \mathrm{cpm} / \mu \mathrm{g}$ of DNA. The labeled DNA was denatured before hybridization by heating at $100^{\circ} \mathrm{C}$ for $5 \mathrm{~min}$ and was then placed on ice.

DNA homology experiments. DNA-DNA homology studies were performed by using the competition procedure of the membrane filter method described by Johnson (19). Competitor DNAs were sonicated (Braun Melsungen, Melsungen, Federal Republic of Germany) at $50 \mathrm{~W}$ for two 15 -s intervals. Membrane filters (type HAHY; Millipore Corp., Bedford, Mass.) containing reference DNA (ca. $25 \mu \mathrm{g} / \mathrm{cm}^{2}$ ) were placed in 5-ml screw cap vials which contained the labeled, sheared, denatured DNA and the denatured and sheared competitor DNA. The ratio of the concentrations of competitor DNA to labeled DNA was at least 150:1. The final volume and concentration was adjusted to $140 \mu \mathrm{l}, 2 \times \mathrm{SSC}$, and $30 \%$ formamide solution. The hybridization temperature ranged between 55 and $58^{\circ} \mathrm{C}$, which is below the limit for the validity of the filter method (8). The vials were shaken slightly for $18 \mathrm{~h}$ in a water bath (Grant Instruments, Cambridge, England); these procedures were done in triplicate. After hybridization the filters were washed in $2 \times \mathrm{SSC}$ at the optimal renaturation temperature. The radioactivity bound to the filters was measured with a liquid scintillation counter (Beckman Instruments, Inc., Palo Alto, Calif.), and the percentage of homology was calculated by using the method of Johnson (19). At least two independent determinations were carried out for each experiment, and the results reported below are the mean values.

\section{RESULTS}

Morphology. All of the strains examined were gramnegative rods, 0.6 to 1.0 by 1.5 to $4.0 \mu \mathrm{m}$. The cells were motile by means of peritrichous flagella. No spores were observed.

Cultural characteristics. The colonies of all strains were circular, smooth, entire, and pigmented characteristically with dark brown centers followed by bluish brown, grayish brown, and yellow rings. They produced a yellow pigment and a violet blue pigment which was not violacein (37). The nature of these pigments is being studied currently.

On liquid medium containing $10 \%$ total salts all of the strains produced turbidity and pellicles and were usually brown.

Physiological, biochemical, and nutritional characteristics. All strains grew in solid media containing 2 to $30 \%(\mathrm{wt} / \mathrm{vol})$ total salts and grew optimally in media containing about $10 \%$ total salts. They grew at temperatures between 5 and $45^{\circ} \mathrm{C}$ and over a $\mathrm{pH}$ range of 5 to 10 , but none grew at $\mathrm{pH} 4$. Production of acid from glucose in the oxidation-fermentation medium of Hugh and Leifson containing $8 \% \mathrm{NaCl}(17)$, in marine oxidation-fermentation medium (23) containing $10 \%$ total salts, and in standard medium (18) containing $10 \%$ total salts was positive in all cases in aerobic tubes but negative under anaerobic conditions. The results of all of the
TABLE 1. Phenotypic characteristics in which the eight strains of Chromohalobacter marismortui differ from one another

\begin{tabular}{|c|c|c|}
\hline Characteristic & $\begin{array}{l}\text { No. of strains } \\
\text { positive }\end{array}$ & $\begin{array}{l}\text { Reaction of strain } \\
\text { ATCC } 17056^{\mathrm{T}}\end{array}$ \\
\hline Nitrate reduction & 7 & $-{ }^{a}$ \\
\hline \multicolumn{3}{|l|}{ Growth on ${ }^{b}:$} \\
\hline Caprylate & 1 & + \\
\hline Propionate & 7 & - \\
\hline Trehalose & 6 & + \\
\hline Lactose & 1 & + \\
\hline L-Rhamnose & 6 & + \\
\hline Starch & 1 & + \\
\hline Adonitol & 1 & + \\
\hline Fumarate & 7 & - \\
\hline Benzoate & 7 & - \\
\hline DL-Glycerate & 7 & - \\
\hline D-Saccharate & 7 & - \\
\hline Quinate & 1 & + \\
\hline Succinate & 7 & - \\
\hline D-Fructose & 7 & - \\
\hline \multicolumn{3}{|l|}{ Growth on ${ }^{c}$ : } \\
\hline Aspartic acid & 1 & + \\
\hline Glutamic acid & 5 & - \\
\hline Glycine & 7 & - \\
\hline L-Histidine & 1 & + \\
\hline DL-Lysine & 7 & - \\
\hline L-Methionine & 7 & - \\
\hline
\end{tabular}

$a+$, Positive; - , negative.

${ }^{b}$ When supplied as the sole source of carbon and energy.

c When supplied as the sole source of carbon, nitrogen, and energy.

physiological and biochemical tests except the nitrate reduction test were the same for all strains; the nitrate reduction test was negative in "Chromobacterium marismortui" ATCC $17056^{\mathrm{T}}$. "Chromobacterium marismortui" ATCC $17056^{\mathrm{T}}$ and the "Chromobacterium marismortui" strain obtained from Elazari-Volcani were identical except in pigmentation, which was less pronounced in the latter. Other characteristics that were common to all of the strains studied are given below in the species description. Characteristics that varied among the eight strains which we studied are shown in Table 1.

DNA base compositions. The DNA base compositions of the strains which we tested are shown in Table 2 and ranged from 62.1 to $64.9 \mathrm{~mol} \% \mathrm{G}+\mathrm{C}$.

DNA-DNA hybridization. The DNA relatedness results obtained with labeled reference DNAs from "Chromobacterium marismortui" ATCC $17056^{\mathrm{T}}$ and strain A-100 are shown in Table 2. The levels of similarity for DNAs from labeled strains to DNAs from the other isolates ranged from 66 to $100 \%$. Low levels of relatedness were found between the two reference strains and the other species used for comparison.

\section{DISCUSSION}

The phenotypic and genotypic results showed that our seven isolates were very similar to "Chromobacterium marismortui" ATCC $17056^{\mathrm{T}}$. This species was originally described by Elazari-Volcani (Ph.D. thesis) and was included in Bergey's Manual, 7th ed. (2). Our results agree with the original description and with the data reported in Bergey's Manual (2), except that the nitrate reduction test was negative for "Chromobacterium marismortui" ATCC $17056^{\mathrm{T}}$. The differences found with respect to the nutritional features can be attributed to the different isolation habitats, since the salt composition and nutrient availability of the Dead Sea are unlike those of the Mediterranean salterns (35). 
TABLE 2. G+C contents of DNAs and levels of DNA-DNA relatedness between Chromohalobacter marismortui and other related species ${ }^{a}$

\begin{tabular}{|c|c|c|c|}
\hline \multirow{2}{*}{ Unlabeled DNA from: } & \multirow{2}{*}{$\begin{array}{l}\mathrm{G}+\mathrm{C} \\
\text { content } \\
\text { (mol\%) }\end{array}$} & \multicolumn{2}{|c|}{$\begin{array}{l}\% \text { Homology } \\
\text { with }{ }^{3} \mathrm{H} \text {-labeled } \\
\text { DNA from: }\end{array}$} \\
\hline & & $\begin{array}{l}\text { Strain } \\
\text { ATCC } \\
17056^{T}\end{array}$ & $\begin{array}{l}\text { Strain } \\
\text { A-100 }\end{array}$ \\
\hline \multicolumn{4}{|l|}{$\begin{array}{l}\text { Chromohalobacter marismortui } \\
\text { strains }\end{array}$} \\
\hline ATCC $17056^{\mathrm{T}}$ & 62.3 & 100 & 91 \\
\hline Elazari-Volcani strain & 62.1 & 100 & 97 \\
\hline A-100 & 62.5 & 87 & 100 \\
\hline A-56 & 63.3 & 91 & 84 \\
\hline A- 65 & 62.4 & 71 & 100 \\
\hline A-102 & 63.7 & 66 & 97 \\
\hline A-429 & 64.1 & 71 & 100 \\
\hline A-431 & 64.9 & 68 & 91 \\
\hline A-492 & 63.9 & 83 & 98 \\
\hline $\begin{array}{l}\text { Chromobacterium violaceum ATCC } \\
12472^{\mathrm{T}}\end{array}$ & $67.2^{b}$ & 14 & 12 \\
\hline $\begin{array}{l}\text { Janthinobacterium lividum ATCC } \\
12473^{\mathrm{T}}\end{array}$ & $65.5^{b}$ & 11 & 22 \\
\hline $\begin{array}{l}\text { Alteromonas luteoviolacea ATCC } \\
33492^{\mathrm{T}}\end{array}$ & $42.1^{c}$ & 20 & 4 \\
\hline Vibrio costicola NCMB $701^{\mathrm{T}}$ & $49.9^{d}$ & 9 & 13 \\
\hline Deleya halophila CCM $3662^{\mathrm{T}}$ & $66.7^{e}$ & 2 & 3 \\
\hline $\begin{array}{l}\text { Flavobacterium halmephilum CCM } \\
2833^{\mathrm{T}}\end{array}$ & $49.7^{f}$ & 28 & 13 \\
\hline Halomonas elongata ATCC $33173^{\mathrm{T}}$ & $60.5^{g}$ & 13 & 19 \\
\hline $\begin{array}{l}\text { "Pseudomonas halosaccharolytica" } \\
\text { CCM } 2851\end{array}$ & $\mathrm{ND}^{h}$ & 15 & 20 \\
\hline
\end{tabular}

${ }^{a}$ Hybridizations were performed under optimal conditions.

$b$ Data from reference 7 .

c Data from reference 13.

${ }^{d}$ Data from reference 12.

e Data from reference 34.

$f$ Data from reference 4

8 Data from reference 41 .

${ }^{h}$ ND, Not determined.

The $\mathrm{G}+\mathrm{C}$ content of "Chromobacterium marismortui" ATCC $17056^{\mathrm{T}}$ was $62.3 \mathrm{~mol} \%$, a value in good agreement with the value reported previously $(61.8 \mathrm{~mol} \%)(7)$ and within the range obtained for the other seven strains studied. The DNA relatedness experiments showed that the seven isolates form a single DNA hybridization group with a high level of homology to "Chromobacterium marismortui" ATCC $17056^{\mathrm{T}}$. Low levels of homology were obtained between the two representative strains and the other gramnegative species studied. "Chromobacterium marismortui" was included as a species incertae sedis in the genus Chromobacterium in Bergey's Manual, 8th ed. (3), since the pigment produced is not violacein and the organism has a different flagellar arrangement. In an extensive study of the genera Chromobacterium and Janthinobacterium, De Ley et al. (7) concluded that "Chromobacterium marismortui' is not a member of either of these genera and that, on the basis of the ribosomal ribonucleic acid similarity maps obtained, "Chromobacterium marismortui" ATCC $17056^{\mathrm{T}}$ " "is either a border case of Pseudomonas section I or a member of a genus closely related to the latter taxon." However, clear differences were found between the strain studied and strains typical of the genus Pseudomonas (32).

Table 3 shows the characteristics that differentiate "Chromobacterium marismortui" from other related species. Since on the basis of phenotypic and genotypic criteria the strains which we studied are not closely related to previously described bacteria, we formally propose that they should be classified in a new genus, Chromohalobacter, as Chromohalobacter marismortui comb. nov., nom. rev.

Description of Chromohalobacter gen. nov. The characteristics of Chromohalobacter (Chro.mo.hal.o.bac'ter. Gr. n. chroma, color; Gr. n. halos, the sea, salt; M.L. n. bacter, rod; M.L. masc. n. Chromohalobacter, colored salt rod). Cells are rods that are 0.6 to 1.0 by 1.5 to $4.0 \mu \mathrm{m}$ when they are grown in the presence of $10 \%$ (wt/vol) salts; at higher and lower salt concentrations, the cells are longer. Gram negative. Motile by means of peritrichous flagella. Endospores are not formed. Colonies are violet blue to brown.

Chemoorganotrophs. Strictly aerobic. Catalase and benzidine tests are positive. Oxidase negative. Optimal growth occurs in media supplemented with $10 \%$ (wt/vol) salt. The optimal temperature is $37^{\circ} \mathrm{C}$, and the optimal pH is 7.5. Acid is produced aerobically but not anaerobically from D-glucose and other sugars. Gelatin, casein, Tween 80 , starch, esculin, and tyrosine are not hydrolyzed. Carbohydrates, amino acids, and some polyols can serve as sole carbon sources.

Habitat: Dead Sea and marine salterns.

The DNA base composition ranges from 62.1 to $64.9 \mathrm{~mol} \%$ $\mathrm{G}+\mathrm{C}$, as determined by the thermal denaturation method.

The type species is Chromohalobacter marismortui.

Description of Chromohalobacter marismortui comb. nov., nom. rev. Chromohalobacter marismortui (ma.ris.mor'tu.i. L. gen. n. maris, of the sea; L. adj. mortuus, dead; M.L. gen. n. marismortui, of the Dead Sea). Gram-negative, nonsporeforming bacteria that are rod shaped (sometimes slightly curved); the length varies with the concentration of salt. At $10 \%$ (wt/vol) total salts, the cells are 0.6 to 1.0 by 1.5 to $4.0 \mu \mathrm{m}$; at higher and lower salts concentrations, the cells are longer. Cells occur singly or in pairs. Motile by means of peritrichous flagella.

On solid, complex media containing $10 \%$ (wt/vol) total salts, colonies are circular, convex, smooth, entire, and concentrically ringed with dark brown centers followed by bluish-brown, grayish brown, and yellow rings. They produce a yellow pigment and a violet blue pigment which is not violacein. Production of pigment is favored by suboptimal growth temperatures, glycerol, and a salt concentration of $10 \%$ (wt/vol). In liquid medium containing $10 \%$ (wt/vol) total salts turbidity and a pellicle are produced; usually brown to yellow pigments are also produced.

Growth occurs from $\mathrm{pH} 5$ to 10 on solid media containing $10 \%$ total salts (optimal growth at $\mathrm{pH} 7.5$ ) and between 5 and $45^{\circ} \mathrm{C}$. The optimum temperature is $37^{\circ} \mathrm{C}$. Growth occurs in media containing 1 to $30 \%$ (wt/vol) salt, with an optimum at about $10 \%$ (wt/vol).

Strictly aerobic. Catalase and benzidine tests are positive. Oxidase negative.

Acid is produced without gas under aerobic conditions in marine oxidation-fermentation medium supplemented with $10 \%(\mathrm{wt} / \mathrm{vol})$ total salts and D-glucose, D-galactose, maltose, lactose, D-arabinose, D-xylose, sucrose, trehalose, glycerol, and D-mannitol. Acid is produced without gas in open Hugh-Leifson tubes with oxidation-fermentation glucose medium containing $8 \% \mathrm{NaCl}$.

Generally, nitrate is reduced to nitrite; nitrite is not reduced. Simmons citrate is utilized.

No hydrolysis of gelatin, casein, starch, esculin, tyrosine, and Tween $80 . \mathrm{H}_{2} \mathrm{~S}$ is not produced from cysteine.

No production of phosphatase, indole, urease, acetoin, deoxyribonuclease, or $\beta$-galactosidase.

No production of phenylalanine deaminase, arginine de- 
TABLE 3. Characteristics useful in distinguishing strains of Chromohalobacter marismortui from other phenotypically similar species ${ }^{a}$

\begin{tabular}{|c|c|c|c|c|c|c|c|c|c|}
\hline Characteristic & 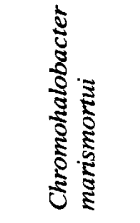 & 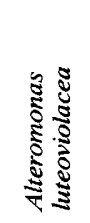 & 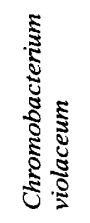 & : & 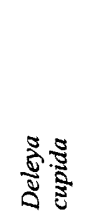 & 胥. & 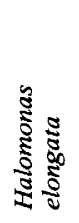 & 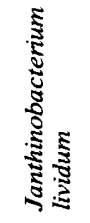 & 胥 \\
\hline Peritrichous flagella & $+t^{b}$ & - & + & + & + & - & + & + & - \\
\hline Facultative anaerobe & - & - & + & - & - & - & + & - & + \\
\hline Pigmentation & + & + & + & - & - & - & - & + & - \\
\hline Oxidase & - & + & + & + & - & - & + & + & + \\
\hline $\mathrm{Na}^{+}$requirement & + & + & - & + & + & + & + & - & + \\
\hline Optimal growth at ca. $10 \%(\mathrm{wt} / \mathrm{vol})$ salt & + & - & - & + & - & - & + & - & + \\
\hline \multicolumn{10}{|l|}{ Acid production from: } \\
\hline D-Glucose & + & d & + & + & ND & ND & + & + & + \\
\hline Trehalose & + & + & + & - & ND & ND & ND & d & + \\
\hline D-Arabinose & + & ND & - & ND & ND & ND & ND & + & - \\
\hline D-Xylose & + & - & - & + & ND & ND & ND & + & - \\
\hline Lactose & + & - & - & - & ND & ND & $\mathrm{d}$ & ND & - \\
\hline Nitrate reduction & + & - & + & + & + & - & + & + & - \\
\hline Nitrite reduction & - & - & + & - & - & - & + & + & - \\
\hline \multicolumn{10}{|l|}{ Hydrolysis of: } \\
\hline Gelatin & - & + & + & - & - & - & d & - & + \\
\hline Casein & - & + & + & - & - & - & - & - & + \\
\hline Starch & - & + & - & - & - & - & - & ND & - \\
\hline Esculin & - & d & - & + & ND & ND & $\mathrm{d}$ & + & d \\
\hline Tween 80 & - & + & + & - & - & - & - & - & d \\
\hline \multicolumn{10}{|l|}{ Growth on ${ }^{c}$ : } \\
\hline D-Fucose & + & ND & ND & ND & - & - & ND & ND & + \\
\hline Butyrate & - & ND & ND & ND & + & + & ND & ND & $\mathrm{d}$ \\
\hline Citrate & - & - & ND & + & + & + & ND & + & d \\
\hline Malonate & - & - & ND & ND & + & + & ND & ND & - \\
\hline \multicolumn{10}{|l|}{ Growth on ${ }^{d}$ : } \\
\hline Betaine & - & ND & ND & ND & + & + & ND & ND & - \\
\hline L-Leucine & - & - & ND & ND & + & + & ND & ND & d \\
\hline Sarcosine & - & ND & ND & ND & + & + & ND & ND & - \\
\hline $\mathrm{G}+\mathrm{C}$ content $(\mathrm{mol} \%)$ & $62.1-64.9$ & $40-43$ & $65-68$ & 66.7 & $60-63$ & $62-64$ & 60.5 & $61-67$ & $49.4-50.5$ \\
\hline
\end{tabular}

Data from this study and references $1,12,13,34,38,39$, and 41 .

${ }^{b}+$, Positive; -, negative; d, differs among strains; ND, not determined.

${ }^{c}$ When supplied as the sole source of carbon and energy.

${ }^{d}$ When supplied as the sole source of carbon, nitrogen, and energy.

hydrolase, lysine decarboxylase, or ornithine decarboxylase.

No hemolysis occurs on blood agar supplemented with $8 \%$ $\mathrm{NaCl}$.

The following compounds are utilized as sole carbon and energy sources: dulcitol, D-fucose, D-galactose, D-gluconate, D-glucose, glutamate, meso-inositol, maltose D-mannitol, D-mannose, pyruvate, D-ribose, sucrose, D-sorbitol, and D-xylose.

The following compounds are not utilized as sole carbon and energy sources: $N$-acetylglucosamine, amygdalin, DL$\alpha$-aminobutyrate, butyrate, cellobiose, citrate, esculin, $p$ hydroxybenzoate, hippurate, inulin, malonate, melibiose, oxalate, raffinose, salicylate, salicin, and D-tartrate.

The following compounds are utilized as sole carbon, nitrogen, and energy sources: L-alanine, DL-arginine, Lglutamine, L-ornithine, L-proline, putrescine, and L-serine.

The following compounds are not utilized as sole carbon, nitrogen, and energy sources: L-allantoin, betaine, creatine, ethionine, L-isoleucine, L-leucine, phenylalanine, sarcosine, $\mathrm{L}$-threonine, and L-valine.

The $\mathrm{G}+\mathrm{C}$ content of the DNA is 62.1 to $64.9 \mathrm{~mol} \%$, as determined by the thermal denaturation method.

Habitat: isolated from the Dead Sea and solar salterns.
The type strain is strain ATCC 17056 (= CCM 3518).

Description of the type strain. The description of the type strain is the same as that of the species. Nitrate is not reduced to nitrite. Other characteristics are listed in Table 1. The $\mathrm{G}+\mathrm{C}$ content of the type strain is $62.3 \mathrm{~mol} \%$, as determined by the thermal denaturation method.

\section{ACKNOWLEDGMENTS}

We thank B. Elazari-Volcani for providing a culture of "Chromobacterium marismortui" and M. Kocur for useful suggestions.

This investigation was supported by grants from the Comisión Asesora para el Desarrollo de la Investigación Cientifica y Técnica and from the Junta de Andalucia.

\section{LITERATURE CITED}

1. Baumann, L., R. D. Bowditch, and P. Baumann. 1983. Description of Deleya gen. nov. created to accommodate the marine species Alcaligenes aestus, $A$. pacificus, $A$. cupidus, $A$. venustus, and Pseudomonas marina. Int. J. Syst. Bacteriol. 33: 793-802.

2. Breed, R. S., E. G. D. Murray, and N. R. Smith (ed.). 1957. Bergey's manual of determinative bacteriology, 7th ed. The Williams \& Wilkins Co., Baltimore.

3. Buchanan, R. E., and N. E. Gibbons (ed.). 1974. Bergey's manual of determinative bacteriology, 8th ed. The Williams \& 
Wilkins Co., Baltimore.

4. Callies, E., and W. Mannheim. 1978. Classification of the Flavobacterium-Cytophaga complex on the basis of respiratory quinones and fumarate respiration. Int. J. Syst. Bacteriol. 28:14-19.

5. Claus, D., F. Fahny, H. J. Rolf, and N. Tosunoglu. 1983. Sporosarcina halophila sp. nov., an obligate, slightly halophilic bacterium from salt marsh soils. Syst. Appl. Microbiol. 4: 496-506.

6. Deibel, R. H., and J. B. Evans. 1960. Modified benzidine test for the detection of cytochrome-containing respiratory systems in microorganisms. J. Bacteriol. 79:356-360.

7. De Ley, J., P. Segers, and M. Gillis. 1978. Intra- and intrageneric similarities of Chromobacterium and Janthinobacterium ribosomal ribonucleic acid cistrons. Int. J. Syst. Bacteriol. 28: 154-168.

8. De Ley, J., and R. Tijtgat. 1970. Evaluation of membrane filter methods for DNA-DNA hybridization. Antonie van Leeuwenhoek J. Microbiol. Serol. 36:461-474.

9. Ferragut, C., and H. Leclerc. 1976. Etude comparative des méthodes de détermination du $\mathrm{T}_{\mathrm{m}}$ de l'ADN bactérien. Ann. Microbiol. (Paris) 127:223-235.

10. Franzmann, P. D., H. R. Burton, and T. A. McMeekin. 1987. Halomonas subglaciescola, a new species of halotolerant bacteria isolated from Antarctica. Int. J. Syst. Bacteriol. 37:27-34.

11. Gaby, W. L., and C. Hadley. 1957. Practical laboratory test for the identification of Pseudomonas aeruginosa. J. Bacteriol. 74:356-358.

12. Garcia, M. T., A. Ventosa, F. Ruiz-Berraquero, and M. Kocur. 1987. Taxonomic study and amended description of Vibrio costicola. Int. J. Syst. Bacteriol. 37:251-256.

13. Gauthier, M. J. 1976. Morphological, physiological, and biochemical characteristics of some violet-pigmented bacteria isolated from seawater. Can. J. Microbiol. 22:138-149.

14. Greenberg, E. P., and E. Canale-Parola. 1976. Spirochaeta halophila sp. n., a facultative anaerobe from a high-salinity pond. Arch. Microbiol. 110:185-194.

15. Hao, M. V., M. Kocur, and K. Komagata. 1984. Marinococcus gen. nov., a new genus for motile cocci with meso-diaminopimelic acid in the cell wall; and Marinococcus albus sp. nov. and Marinococcus halophilus (Novitsky and Kushner) comb. nov. J. Gen. Appl. Microbiol. 30:449-459.

16. Hebert, A. M., and R. H. Vreeland. 1987. Phenotypic comparison of halotolerant bacteria: Halomonas halodurans sp. nov., nom. rev., comb. nov. Int. J. Syst. Bacteriol. 37:347-350.

17. Hugh, R., and E. Leifson. 1953. The taxonomic significance of fermentative versus oxidative metabolism of carbohydrates by various Gram-negative bacteria. J. Bacteriol. 66:24-26.

18. International Committee on Taxonomy Subcommittee on Taxonomy of Staphylococci and Micrococci. 1965. Recommendations. Int. Bull. Bacteriol. Nomencl. Taxon. 15:109-110.

19. Johnson, J. L. 1981. Genetic characterization, p. 450-472. In P. Gerhardt, R. G. E. Murray, R. N. Costilow, E. W. Nester, W. A. Wood, N. R. Krieg, and G. B. Phillips (ed.), Manual of methods for general bacteriology. American Society for Microbiology, Washington, D.C.

20. Kocur, M. 1984. Genus Paracoccus, p. 399-402. In N. R. Krieg and J. G. Holt (ed.), Bergey's manual of systematic bacteriology, vol. 1. The Williams \& Wilkins Co., Baltimore.

21. Kovacs, N. 1956. Identification of Pseudomonas pyocyanea by the oxidase reaction. Nature (London) 178:703.

22. Kushner, D. J. 1985. The Halobacteriaceae, p. 171-214. In C. R. Woese and R. S. Wolfe (ed.), The bacteria: a treatise on structure and function, vol. 8. Academic Press Inc. (London), Ltd., London.

23. Leifson, E. 1963. Determination of carbohydrate metabolism of marine bacteria. J. Bacteriol. 85:1183-1184.

24. Marmur, J. 1961. A procedure for the isolation of deoxyribonucleic acid from micro-organisms. J. Mol. Biol. 3:208-218.

25. Marmur, J., and P. Doty. 1962. Determination of the base composition of deoxyribonucleic acid from its thermal denaturation temperature. J. Mol. Biol. 5:109-118.

26. Mathrani, I. M., D. R. Boone, R. A. Mah, G. E. Fox, and P. P. Lau. 1988. Methanohalophilus zhilinae sp. nov., an alkaliphilic halophilic, methylotrophic methanogen. Int. J. Syst. Bacteriol. 38:139-142.

27. Onishi, H., and M. Kamekura. 1972. Micrococcus halobius sp. n. Int. J. Syst. Bacteriol. 22:233-236.

28. Oren, A., H. Pohla, and E. Stackebrandt. 1987. Transfer of Clostridium lortetii to a new genus, Sporohalobacter gen. nov. as Sporohalobacter lortetii comb. nov., and description of Sporohalobacter marismortui sp. nov. Syst. Appl. Microbiol. 9:239-246.

29. Oren, A., W. G. Weisburg, M. Kessel, and C. R. Woese. 1984. Halobacteroides halobius, gen. nov., sp. nov., a moderately halophilic anaerobic bacterium from the bottom sediments of the Dead Sea. Syst. Appl. Microbiol. 5:58-70.

30. Owen, R. J., and L. R. Hill. 1979. The estimation of base compositions, base pairing and genome size of bacterial deoxyribonucleic acids, p. 217-296. In F. A. Skinner and D. W. Lovelock (ed.), Identification methods for microbiologists, 2nd ed. Academic Press, Inc. (London), Ltd., London.

31. Owen, R. J., and D. Pitcher. 1985. Current methods for estimating DNA base composition and levels of DNA-DNA hybridization, p. 67-93. In M. Goodfellow and E. Minnikin (ed.), Chemical methods in bacterial systematics. Academic Press, Inc. (London), Ltd., London.

32. Palleroni, N. J. 1985. Genus 1. Pseudomonas, p. 141-199. In N. R. Krieg and J. G. Holt (ed.), Bergey's manual of systematic bacteriology, vol. 1. The Williams and Wilkins Co., Baltimore.

33. Paterek, J. R., and P. H. Smith. 1988. Methanohalophilus mahii gen. nov., sp. nov., a methylotrophic halophilic methanogen. Int. J. Syst. Bacteriol. 38:122-123.

34. Quesada, E., A. Ventosa, F. Ruiz-Berraquero, and A. RamosCormenzana. 1984. Deleya halophila, a new species of moderately halophilic bacteria. Int. J. Syst. Bacteriol. 34:287-292.

35. Rodriguez-Valera, F. 1988. Characteristics and microbial ecology of hypersaline environments, p. 3-31. In F. RodriguezValera (ed.), Halophilic bacteria, vol. 1. Academic Press, Inc. (London), Ltd., London.

36. Skerman, V. B. D., V. McGowan, and P. H. A. Sneath (ed.). 1980. Approved lists of bacterial names. Int. J. Syst. Bacteriol. 30:225-420.

37. Sneath, P. H. A. 1979. Identification methods applied to Chromobacterium, p. 167-175. In F. A. Skinner and D. W. Lovelock (ed.), Identification methods for microbiologists, 2nd ed. Academic Press, Inc. (London), Ltd., London.

38. Sneath, P. H. A. 1984. Genus Janthinobacterium, p. 376-377. In N. R. Krieg and J. G. Holt (ed.), Bergey's manual of systematic bacteriology, vol. 1. The Williams \& Wilkins Co., Baltimore.

39. Sneath, P. H. A. 1984. Genus Chromobacterium, p. 580-582. In N. R. Krieg and J. G. Holt (ed.), Bergey's manual of systematic bacteriology, vol. 1. The Williams \& Wilkins Co., Baltimore.

40. Ventosa, A., E. Quesada, F. Rodriguez-Valera, F. Ruiz-Berraquero, and A. Ramos-Cormenzana. 1984. Numerical taxonomy of moderately halophilic Gram-negative rods. J. Gen. Microbiol. 128:1959-1968.

41. Vreeland, R. H., C. D. Litchfield, E. L. Martin, and E. Elliot. 1980. Halomonas elongata, a new genus and species of extremely salt-tolerant bacteria. Int. J. Syst. Bacteriol. 30:485495 .

42. Yu, I. K., and F. Kawamura. 1987. Halomethanococcus doii gen. nov. sp. nov.: an obligately halophilic methanogenic bacterium from solar salt ponds. J. Gen. Appl. Microbiol. 33: 303-310.

43. Zeikus, J. G., P. W. Hegge, T. E. Thompson, T. J. Phelps, and T. A. Langworthy. 1983. Isolation and description of Haloanaerobium praevalens gen. nov. and sp. nov., an obligately anaerobic halophile common to Great Salt Lake sediments. Curr. Microbiol. 9:225-234. 